\title{
On English listening teaching for non-English major college students
}

\author{
Fan Ming \\ Dalian University, Dalian, Liaoning, 116000
}

Keywords:Non-English majors; Listening; Teaching

\begin{abstract}
Language is the embodiment of human mind, an important tool for people to communicate and important carrier of consciousness. To learn English well is to ensure their condition with sufficient competitiveness. To learn a language, first is to be able to "listen" and "speak", then "read" and "write". In college English learning, what students feel the hardest is the improvement of listening comprehension. This paper analyzes non-English major students listening learning situation and existing problems, and several factors influencing the improvement of listening, then puts forward practical and feasible methods to improve the level of English listening.
\end{abstract}

\section{Introduction}

As an input skill, listening is one of the most basic conditions to measure one's English level. The ability of listening comprehension is an important part of language using ability, and a very important aspect for English teaching. While testing English, listening comprehension has the highest proportion. Listening is the brain's complex analysis and understanding of synthesis process of the material conforming to the standards of listening, and the brain's processing and finishing all process of the voice introduced into the ear. At the time of learning English, listening is the foundation and the key. Input all information into the brain, and then there would be various outputs [1]. While people are engaged in communication activities, $9 \%$ of the time is used for writing, $16 \%$ of the time is for reading, and $30 \%$ of the time is used to say, while $45 \%$ of the time is to listen. As the further carrying out of national ministry of education's “College English Teaching Reform”, the teaching ideas giving priority to hearing and speaking have been penetrated into our daily college English teaching. Reforms of CET exams therefore are improving listening comprehension part in quantity and proportion. Listening comprehension quantity increased from 20 questions to 35, which is from $20 \%$ to $35 \%$. Thus, listening teaching holds quite important status in the whole hog of English teaching. But in actual communication and teaching, we cannot deny that listening is the biggest obstacle for college students’ learning English and using English.

\section{Non-English major students' listening situation and existing problems}

Many non-English major college students are not interested in English hearing. They lack of consciousness of listening practice, so they seldom practice. In actual listening test, they haven't mastered the skills of listening [2]. They do not know to browse the listening material to increase its familiar degree in advance, and also have no consciousness of written record work in the process of listening. When they meet new words and obscure words, they would stick, and are unable to concentrate in the follow-up of the material. Thus leads to a number of students 'bad result in English test CET band 4 and band 6, and other tests containing hearing. There are many factors affecting listening comprehension, such as vocabulary word-base, English countries' cultural background knowledge and the listeners' psychological factors, judgment reasoning, and pronunciation knowledge, etc. Ma Wangchao pointed out that "College English students have a common characteristic, that is, they know almost all of the words written on the blackboard, but while others read or speak in the correct pronunciation and intonation, they don't understand. That is to say, students' pronunciation of the words in mind can't match with the correct pronunciation. When they hear English sentences, they can't find the corresponding 'sound' material base in the cerebral cortex, let alone how to write, of course, not to mention " output " the information they heard in their own words on the basis of understanding the original meaning[3].

\section{The main factors influencing listening ability}

\section{A. Pronunciation barrier}

Listening has a lot to do with pronunciation, many of the non-English major students do not 
remember the correct pronunciation of words at the beginning of their studying of words, and learn words with only their own pronunciation memory and standard. Because the pronunciation is different, it causes the insufficient hearing ability. For example, they are not sure exactly which word it is when listening to words with the same pronunciation, and cannot make correct identification. There are intonation reasons. In English expression habit, there are different intonations. Students 'words distinguishing ability is insufficient. Although many words are in basic vocabulary, when students listen to the tape, they cannot write them down. Even if some students can write, the words written are also wrong. This fully reflects that students are not enough sensitive to the pronunciation of English words, or students at ordinary times did not attach enough importance to standard pronunciation. When there is an even read, weak blasting, assimilation, incomplete, and so on and so forth, the distinguishing ability of students is especially weak.

\section{$B$. Vocabulary obstacles}

Students' vocabulary volume and the ability of combination of words largely decide if the effect of language learning is ideal or not. If you meet too many new words in the process of listening, it is hard to understand the meaning. Of course, the following circumstances also often appear. "In listening tests, subjects often feel clearly that they heard everything, and didn't find unfamiliar words, but they were very forgetful, or they could not process meaningful and coherent information" [4]. This is because the brain's short-term storage capacity is limited. Many students just write several incoherent words, even a lot of spelling mistakes. The reasons are that most students have not master words, and words block combination ability is weak, so they cannot seize the sentence main idea, and it is difficult to record what they hear in a timely manner.

\section{Weak grammar}

English has formed its own unique language rules in the process of its formation and development. There is a big difference between it and Chinese language rules, and is completely different from Chinese minority language rules. Therefore, if Chinese students don't understand English language rules and linguistic phenomenon, and understand English according to the syntax rules of mother tongue, it is hard to learn English well. And, a lot of grammar knowledge such as comparative, negatives, subjunctive mood are often appear in listening material and oral communication. If students have good grammar knowledge, it's easy to understand the idea; whereas it is hard to catch the instant message, and leads to obstacles to correct understanding of the listening material.

\section{Lack of cultural background knowledge}

Students lack the understanding of the background knowledge of foreign culture and the material. British social anthropologist Malinowski (1923) said: "language deeply roots in cultural display and the custom of the nations' peoples 'life. Language study cannot leave the broad environment of language behavior." Cultural background knowledge has a great influence on listening. Some students take listening as an isolated ability of listening skills, but it is wrong. Listening comprehension ability is inseparable from the study and understanding of cultural background knowledge such as custom and religious history of Britain and the United States and other countries.

\section{The measures to improve non-English major students' listening ability}

\section{A. Reading aloud}

Reading is the important factors that affect students' listening level, to improve the English listening teaching in our country, attaches great importance to reading aloud is a link cannot be ignored. Read special physiological and psychological characteristics is of great significance to the listening comprehension, and an increase in language and culture background knowledge, increase self-confidence, improve the knowledge skills and effective voice memory and so on is beneficial to the improvement of listening comprehension. A large number of accurate reading training can strengthen the grasp and understanding of the listening material. Only reading in English teaching is teaching, let the hearing to promote reading, reading aloud to improve listening comprehension, can better improve the efficiency of listening to English. Reading is the foundation of listening. $\mathrm{Xu}$ Guozhang once said, learn pronunciation well, then you will reap the fruits. This sentence is true. Only by reading right can others understand you. Let the pronunciation of each word leaves an impression in the brain. Once listen again about the word, the impression in the brain corresponds and react quickly, which would be easier to understand.

$B$. Targeted training on elements and techniques using in listening 
Factors associated with hearing including pronunciation, intonation, rhythm and sense groups, assimilation and various liaison and weakening, etc. Pronunciation is also very important in listening, especially the phoneme discrimination, such as: phoneme contrast, consonant clusters, strong, weak, liaison and stress, elision, etc.; Identify the meaning, such as the judgment of the characters in situation dialogue, location, time and events, etc. will affect the understanding of listening material. Techniques such as stress, weak reading, liaison, plenum abate, intonation, sense groups play important roles in listening understanding. The change of tone and stress changes the meaning of statements, and brings different meaning to the sentence. Sense group distinction may also affect the listener's understanding of the sentence. Teachers can strengthen the distinctions by giving models in class, or let the students imitate stress, intonation, and divide the meaning group, etc.

In actual listening test and evaluation, there are many techniques can be applied. Such as when meet strange words you don't understand, directly remember the pronunciation of the general first, and don't struggle with its specific meaning. After listening, carefully think about its possible meaning. In CET exams, for listening part, students should preview the answers roughly once, get ready in heart, then while listening, they don't feel too strange. When listening, appropriately do some written record work. It could be a certain assistance provided for understanding. When teaching techniques, first can be brainstorm, play students collective role, and make brainstorming activities for the students, then communicate and transfer listening skills.

C. Summary after listening.

Penny Ur regarded that after the listening activities, teachers should give feedback in a timely manner on students 'completion of the task. In the process of feedback, teachers can let students evaluate their own tasks. After the feedback, the teacher has to consolidate the listening contents. First of all, summarize the vocabulary, basic sentence patterns and expressions in listening material; Then according to the actual situation, perform role play and group discussion in the listening material. By language learning, let students better understand and grasp knowledge, so as to promote students' language ability of practical application.

D. Strengthen students' listening training

Listening is a difficult work, but can also be strengthened through proper training. The socalled practice makes perfect means that strengthening the practice of listening, to a large extent, can improve students' listening ability. Most non-English major students do not have the habit of consciously listening training, so we must strengthen listening level and quality. Teachers should handle them through some hard and fast rules or more creative ways, such as by listening to English songs, watching English movies and read some English short plays and listening contest. Through these ways, strengthen listening training of students.

\section{Conclusion}

The target of new century college English teaching is to cultivate compound talents of English creation ability and communication ability, so college English listening is more and more important. For non-English major students, listening training is a long-term and arduous task. In the actual teaching, teachers are required to take ways of science on the one hand to solve the problems of students' listening, on the other hand, continuously to improve students' English listening ability and quality, and help students to improve overall English literacy, and lay a solid language and knowledge base for them to go towards the world.

\section{References}

[1] Zhao Yanxia, Hao Mei. Self-management research in whole process college English writing teaching--- a study of non-English major students' classroom experiment [J]. Journal of Xinzhou Teachers College. 2011 (3)

[2] Lv Jianjun. How to cultivate and improve the ability of middle school students' English listening comprehension [J]. Modern Reading (Education), 2011 (11)

[3] Ma Jianchao. College English teaching from compound dictation [J]. Foreign Language World. $2002(02)$

[4] Li Junlan. Foreign language learning anxiety influence on listening comprehension [J]. Journal of Yuncheng University. 2005 (3) 